\title{
Pengaruh Model Problem Based Learning (PBL) Berbasis Portofolio Terhadap Hasil Belajar IPS
}

\author{
Ida Ayu Ketut Manik Loka Andari ${ }^{1 *}$, I Wayan Darsana², Agung Sri Asri ${ }^{3}$
}

${ }^{123}$ Universitas Pendidikan Ganesha, Singaraja, Indonesia

\author{
A R T I C LEINFO \\ Article history: \\ Received 18 August 2019 \\ Received in revised form \\ 19 September 2019 \\ Accepted 25 October 2019 \\ Available online 30 \\ November 2019 \\ Kata Kunci: \\ Problem Based Learning, \\ Portofolio, Hasil Belajar IPS \\ Keywords: \\ Problem Based Learning, \\ Portfolio, Social Science Study \\ Results.
}

\begin{abstract}
A B S T R A K
Penelitian ini bertujuan untuk mengetahui pengaruh yang signifikan hasil belajar IPS antara peserta didik yang dibelajarkan dengan Model Problem Based Leaming (PBL) Berbasis Portofolio dan peserta didik yang mengikuti dengan pembelajaran konvensional pada peserta didik kelas IV di Gugus II Abiansemal tahun ajaran 2017/2018. Jenis penelitian ini adalah penelitian eksperimen semu, dengan desain Nonequivalent Control Group Design. Populasi penelitian ini adalah seluruh kelas IV SD di Gugus II Abiansemal yang berjumlah 232 orang. Penentuan sampel dalam penelitian ini dilakukan dengan teknik random sampling yang diacak adalah kelasnya untuk menentukan kelas eksperimen dan kelas control dengan hasil pengundian yaitu peserta didik kelas IV SD No. 1 Selat yang berjumlah 30 orang sebagai kelompok eksperimen dan peserta didik kelas IV SD No. 2 Taman yang berjumlah 30 orang sebagai kelompok kontrol. Metode pengumpulan data dalam penelitian ini adalah metode tes dalam bentuk tes objektif pilihan ganda biasa. Data yang diperoleh dianalisis menggunakan uji-t. Berdasarkan, hasil analisis data, diperoleh $t_{\text {hitung }}=2,869>t_{\text {tabel }}=2,000$ pada taraf signifikansi $5 \%$ dengan $\mathrm{dk}=\mathrm{n} 1+\mathrm{n} 2-2=(30+30-2)=58$. Rata-rata hasil belajar IPS siswa kelompok eksperimen $\bar{X}=78,57>\bar{X}=72,17$ rata-rata hasil belajar IPS siswa kelompok kontrol. Dengan demikian dapat disimpulkan bahwa terdapat pengaruh model Problem Based Learning (PBL) Berbasis Portofolio terhadap hasil belajar IPS peserta didik kelas IV sekolah dasar gugus II Abiansemal Tahun Ajaran 2017/2018.
\end{abstract}

\section{A B S T R A C T}

This research aims to know the significant influence the results of Social Sciences between learners who with the Model of Problem Based Learning (PBL)-based portfolio and learner who follows with the conventional learning at the students of fourth grade in Cluster II Abiansemal 2017/2018academic year. This research was quasi experimental research, design with Nonequivalent Control Group Design. The population of this research is the entire fourth grade elementary school in the cluster II Abiansemal amount to 232 students. Determination of the sample in this research was conducted with a random sampling technique was contrary to his class to specify the class and grade control experiments with the results of the draw i.e. learners fourth grade elementary school No.1 Selat amounted to 30 students as experimental groups and learners fourth grade elementary school No. 2 Taman amounted to 30 people as a control group. The data collection method in this research is a method of test in the form of multiple choice objective test. The data obtained were analyzed using ttest. Based on the results of data analysis, retrieved thitung $=$ ttabel $>2.869=2.000$ on $5 \%$ significance level with $\mathrm{dk}=\mathrm{n} 1+\mathrm{n} 2-2=(30+30-2)=58$. The average results of the experimental group of students studying IPS $=78.57>=72.17$ results average learning IPS students control group. Thus it can be concluded that there is a influence of the Problem Based Learning (PBL) portfoliobased learning outcomes against Social Sciences learners fourth grade elementary school cluster II Abiansemal in 2017/2018 academic year.

\footnotetext{
${ }^{1}$ Corresponding author.

E-mail addresses:oka.andari@undiksha.ac.id, (Ida Ayu Ketut Manik Loka Andari)
} 


\section{Pendahuluan}

Pendidikan merupakan suatu proses dalam membelajarkan peserta didik supaya mampu menyesuaikan diri dengan lingkungan dan dapat meningkatkan kualitas sumber daya manusia (SDM) dalam menjamin keberlangsungan suatu bangsa. Hal ini tertuang dalam Undang-Undang Nomor 20 Tahun 2003 tentang Sistem Pendidikan Nasional yang bertujuan untuk berkembangnya potensi peserta didik agar menjadi manusia yang beriman dan bertakwa kepada Tuhan Yang Maha Esa, berakhlak mulia, berilmu, cakap, kreatif, mandiri, dan menjadi warga negara yang demokratis serta bertanggung jawab. Dengan demikian pendidikan sangatlah penting bagi peserta didik dan lebihnya lagi bagi masyarakat. Pada pelaksanaan pendidikan di sekolah dasar, maka perlu adanya kurikulum untuk mendukung proses pendidikan yang lebih baik.

Pendidikan lebih dari sekedar pengajaran, yang dapat dikatakan sebagai suatu proses transfer ilmu, transformasi nilai, dan pembentukan kepribadian dengan segala aspek yang dicakupnya. Dengan demikian pengajaran lebih berorientasi pada pembentukan spesialis atau bidangbidang tertentu, oleh karena itu perhatian dan minatnya lebih bersifat teknis. Pendidikan merupakan suatu proses yang diperlukan untuk mendapatkan keseimbangan dan kesempurnaan dalam perkembangan individu maupun masyarakat. Penekanan pendidikan dibanding dengan pengajaran terletak pada pembentukan kesadaran dan kepribadian individu atau masyarakat di samping transfer ilmu dan keahlian. Dengan proses semacam ini suatu bangsa atau negara dapat mewariskan nilai-nilai keagamaan, kebudayaan, pemikiran dan keahlian kepada generasi berikutnya, sehingga mereka betul-betul siap menyongsong masa depan kehidupan bangsa dan negara yang lebih cerah. Pendidikan juga merupakan sebuah aktifitas yang memiliki maksud atau tujuan tertentu yang diarahkan untuk mengembangkan potensi yang dimiliki manusia baik sebagai manusia ataupun sebagai masyarakat dengan sepenuhnya (Nurkholis, 2013).

Gunawan (2016:49) menjelaskan, "kurikulum adalah rencana dan pengaturan mengenai tujuan, isi, dan bahan pelajaran serta cara yang dipergunakan sebagai pedoman penyelenggaraan kegiatan pembelajaran untuk mencapai tujuan pendidikan tertentu". Berdasarkan Undang-Undang Nomor 20 Tahun 2003 tentang Sistem Pendidikan Nasional pasal 36 Ayat (2) ditegaskan bahwa kurikulum pada semua jenjang dan jenis pendidikan dikembangkan dengan prinsip diverifikasi sesuai dengan satuan pendidikan, potensi daerah dan peserta didik. Atas dasar pemikiran tersebut maka perlu dikembangkan Kurikulum Tingkat Satuan Pendidikan (KTSP). Dalam Kurikulum 2006 (KTSP) mengacu pada standar isi dan standar kompetensi lulusan. Melalui Kurikulum Tingkat Satuan Pendidikan (KTSP) guru dituntut untuk mengembangkan rencana pelaksanaan pembelajaran (RPP) berdasarkan kompetensi dasar (KD) yang dapat digali dan dikembangkan oleh peserta didik. Guru merupakan faktor penting yang perlu diperhatikan dalam sebuah kurikulum dan implementasinya dalam pembelajaran. Sebab bagaimanapun baiknya suatu kurikulum jika tidak ditunjang oleh pemahaman dan kompetensi guru maka dalam implementasinya di sekolah akan berakibat kegagalan. Oleh karena itu, untuk menyukseskan implementasi KTSP perlu ditunjang oleh guru yang berkulitas, dan mampu menganalisis pesan-pesan kurikulum. Maka dengan itu guru dan peserta didik dapat bersama-sama menggali kompetensinya masing-masing dengan optimal.

Dalam struktur Kurikulum Tingkat Satuan Pendidikan memuat 8 mata pelajaran yang diantaranya terdapat mata pelajaran IPS. Ilmu Pengetahuan Sosial (IPS), merupakan salah satu muatan mata pelajaran yang di berikan di SD. Gunawan (2016:51) menyatakan "IPS merupakan salah satu mata pelajaran yang mengkaji seperangkat peristiwa, fakta, konsep, dan generalisasi yang berkaitan dengan isu sosial. Memuat materi geografi, sejarah, sosiologi, dan ekonomi". Sejalan dengan Susanto, (2013:139) "IPS merupakan perpaduan antara ilmu sosial dan kehidupan manusia yang di dalamnya mencakup antropologi, ekonomi, geografi, sejarah, hokum, filsafat, ilmu politik, sosiologi, agama, dan psikologi".

Pendidikan IPS di sekolah dasar meupakan bidang studi yang mempelajari manusia dalam semua aspek kehidupan dan interaksinya dalam masyarakat. Peranan IPS sangat penting untuk mendidik peserta didik dalam mengembangkan pengetahuan, sikap, dan keterampilan agar dapat mengambil bagian secara aktif dalam kehidupannya kelak. Materi pembelajaran IPS penuh dengan pesan yang bersifat abstrak. Konsep-konsep seperti waktu, perubahan lingkungan, demokrasi dan nilai merupakan konsepkonsep dalam program studi IPS yang perlu diajarkan kepada peserta didik di SD. Ariswati (2017: vol 6) menyatakan, "pembelajaran IPS mengembangkan pengetahuan dan keterampilan dasar yang berguna bagi peserta didik dalam kehidupan sehari - hari agar peserta didik peka terhadap masalah sosial yang terjadi di lingkungan masyarakat dan terampil mengatasi setiap masalah yang terjadi". Salah satu cara dalam proses pembelajaran agar lebih bermakna maka perlu adanya pembelajaran yang inovatif. Oleh karena itu, guru harus mampu mengembangkan ide yang kreatif serta pembelajaran yang inovatif dalam pembelajaran yang menarik dan bermakna untuk peserta didik karena pada saat proses pembelajaran 
yang dilakukan secara konvensional saja tidaklah cukup untuk mendukung proses pembelajaran di dalam kelas.

Indikator yang dapat menunjukkan keberhasilan dalam suatu proses pembelajaran adalah hasil belajar. Menurut Susanto (2013) mengemukakan bahwa hasil belajar yaitu perubahan yang terjadi pada diri peserta didik baik yang menyangkut aspek kognitif, afektif maupun psikomotor sebagai hasil dari kegiatan belajar. Hasil belajar juga merupakan prestasi belajar yang dicapai peserta didik dalam proses belajar mengajar. Maka dari itu untuk menyatakan bahwa suatu proses belajar dikatakan berhasil, setiap guru memiliki pandangannya masing-masing. Di dalam pembelajaraan dipengaruhi oleh faktor internal dan faktor eksternal. Faktor internal merupakan faktor yang bersumber dari dalam diri peserta didik sedangkan faktor eksternal merupakan faktor yang bersumber dari luar diri peserta didik. Faktor eksternal yang dimaksud salah satunya adalah guru, karena guru merupakan komponen yang sangat menentukan dalam implementasi suatu strategi pembelajaran. Jadi, guru sangat berperan penting dalam memengaruhi hasil belajar peserta didik.

Dari hasil observasi awal pada tanggal 22 Januari 2018 di masing - masing SD di Gugus II Abiansemal, maka diketahui bahwa sebagian besar guru belum mengadakan variasi penerapan model pembelajaran. Guru lebih banyak menyampaikan materi pelajaran melalui ceramah, penugasan, dan tanya jawab. Dilihat juga dari nilai raport Ulangan Akhir Semester I (UAS), Kriteria Ketuntasan Minimal (KKM) yang ditetapkan sekolah untuk mata pelajaan IPS adalah 74, dari 232 peserta didik yang mendapatkan nilai di atas KKM sebanyak 110 atau $47,41 \%$ peserta didik yang sudah mencapai nilai yang diharapkan sedangkan siswa yang masih di bawah KKM sebanyak 122 atau 52,58\% peserta didik yang belum mampu menunjukkan hasil belajar yang baik. Berkaitan dengan hal ini banyak faktor yang mempengaruhi hal tersebut, setelah melaksanakan observasi teridentifikasi masalah - masalah yang berkaitan dengan rendahnya hasil belajar peserta didik seperti : a) peserta didik hanya berperan sebagai penerima informasi sehingga pemahaman yang di dapat peserta didik terbatas hanya dari apa yang mereka dengar, b) kurang bervariasinya model pembelajaran pada saat proses pembelajaran, c) peserta didik kurang aktif dalam proses pembelajaran. Dari beberapa permasalahan yang dapat ditemui maka perlu dikembangkan model-model yang bervariasi agar peserta didik lebih aktif dalam mengikuti pembelajaran di kelas. Untuk mencapai hasil belajar yang maksimal tentunya guru perlu merancang pembelajaran yang menyenangkan dan inovatif. Dengan demikian, peran guru sangat penting dalam membantu peserta didik untuk membangkitkan rasa ingin tahu, menciptakan kondisi belajar yang kondusif dan memberi kesempatan peserta didik untuk berperan aktif, sehingga hasil belajar yang ideal akan tercapai dan terjadi peningkatan pemahaman pada peserta didik. Untuk mencapai tujuan tersebut, guru harus menggunakan pendekatan, strategi, model/metode pembelajaran yang inovatif.

Pembelajaran Berbasis Masalah adalah salah satu model yang inovatif yang dapat memberikan kondisi belajar aktif pada peserta didik. Pembelajaran dengan model PBL merupakan pembelajaran yang penyampaiannya dilakukan dengan menyajikan suatu masalah kontekstual untuk melatih dan meningkatkan keterampilan berpikir kritis dan pemecahan masalah sehingga peserta didik dapat menyusun pengetahuannya sendiri. Sumantri (2015) mengartikan PBL merupakan salah satu model pembelajaran inovatif yang dapat memberikan kondisi belajar aktif dan melibatkan peserta didik untuk memecahkan suatu masalah melalui tahap-tahap metode ilmiah sehingga peserta didik dapat mempelajari pengetahuan yang berhubungan dengan masalah tersebut serta sekaligus memiliki keterampilan untuk memecahkan masalah. Ariwati (2017: vol 6) menyatakan, model problem based learning selain membantu peserta didik memahami konsep - konsep yang sulit, juga berguna untuk membantu peserta didik untuk mengembangkan keterampilan, menyelesaikan masalah, dan berpikir kritis serta dapat bekerja sama dalam memecahkan permasalahan sekaligus membangun pengetahuan baru secara berpasangan atau berkelompok. Dewi (2017) menyatakan, "model Problem Based Learning mampu mengembangkan kemampuan peserta didik dalam berpikir kritis serta dapat bekerja sama dengan baik dalam memecahkan permasalahan pembelajaran dan siswa dapat membangun pengetahuannya sendiri". Keunggulan dari PBL adalah mendorong peserta didik aktif berpikir, memberi kesempatan kepada peserta didik untuk menanyakan hal-hal yang kurang jelas sehingga guru dapat menjelaskan kembali, perbedaan pendapat atara peserta didik dapat dikompromikan atau diarahkan, dan sebagai cara meninjau kembali (review) bahan pelajaran yang lampau. Sehingga dapat dirangkum bahwa model Problem Based Learning adalah model pembelajaran inovatif yang dapat memberikan kondisi belajar aktif dan penyampaiannya dilakukan dengan menyajikan suatu masalah kontekstual untuk melatih dan meningkatkan keterampilan berpikir kritis dan pemecahan masalah sehingga peserta didik dapat menyusun pengetahuannya sendiri.

Untuk mengetahui prestasi peserta didik, guru dapat menggunakan portofolio sebagai dokumen yang digunakan peserta didik untuk menyimpan hasil belajarnya. Surapranata (2007) menyatakan "portofolio merupakan kumpulan hasil evidence atau hasil belajar atau karya peserta didik yang 
menunjukkan usaha, perkembangan, prestasi belajar peserta didik dari waktu ke waktu". Sejalan dengan Muslich (2007) "portofolio merupakan kumpulan karya (hasil kerja) seorang peserta didik dalam periode tertentu. Kumpulan karya ini menggambarkan taraf kompetensi yang dicapai seorang peserta didik". Portofolio digunakan oleh peserta didik untuk mengumpulkan dokumen yang berkaitan dengan hasil karyanya baik yang diperoleh di sekolah maupun diluar sekolah. Putra (2017) menyatakan, "dengan adanya portofolio dalam proses pembelajaran guru dapat mengetahui perkembangan peserta didik secara individu serta memberikan perbaikan dalam hasil belajar yang kurang optimal". Dengan ini guru dapat mengetahui peserta didik yang kurang aktif dalam mengikuti pembelajaran dan guru dapat mengambil tindak lanjut untuk mengoptimalkan hasil belajar peserta didik, dengan demikian dapat disimpulkan bahwa pengaruh model PBL berbasis Portofolio meruapakan pembelajaran yang inovatif yang membuat peserta didik lebih aktif dalam proses pembelajaran dan dibantu dengan portofolio guru dapat mengetahui perkembangan hasil belajar IPS melalui kumpulan hasil karya peserta didik yang diperoleh selama proses belajar.

Berdasarkan uraian latar belakang di atas, maka dilakukan penelitian eksperimen yang berjudul "Pengaruh Model Problem Based Learning (PBL) Berbasis Portofolio Terhadap Hasil Belajar IPS Siswa Kelas IV SD Gugus II Abiansemal Tahun Ajaran 2017/2018”.

\section{Metode}

Penelitian ini dilaksanakan pada semester genap tahun ajaran 2017/2018 di SD Gugus II Abiansemal yang bertujuan untuk mengetahui pengaruh model Problem Based Learning berbasis portofolio dengan peserta didik yang diberikan perlakuan model pembelajaran konvensional terhadap hasil belajar IPS peserta didik. Jenis penelitian ini adalah eksperimen semu (Quasi Experiment), rancangan penelitian yang digunakan adalah Nonequivalent Control Group Design. Adapun rancangan penelitian yang digunakan adalah Nonequivalent Control Group Design sebagai berikut:

\begin{tabular}{|lll|}
\hline \multicolumn{3}{|c|}{ Desain Penelitian } \\
$\mathbf{O}_{\mathbf{1}}$ & $\mathbf{X}$ & $\mathbf{O}_{\mathbf{2}}$ \\
$-\mathbf{O}_{3}$ & & $\mathbf{O}_{\mathbf{4}}$ \\
\hline
\end{tabular}

(Sugiyono, 2011:79)

\section{Gambar 1. Non-equivalent Control Group Design}

Dalam desain ini, ada dua kelompok subjek yakni satu kelompok eksperimen dan satu kelompok sebagai kelompok kontrol. Kelompok eksperimen mendapat perlakuan khusus dengan menerapkan model Problem Based Learning berbasis portofolio sedangkan untuk kelompok kontrol diterapkan pembelajaran konvensional. Kedua kelompok memperoleh prestest dan posttest

Populasi adalah wilayah generalisasi yang terdiri atas objek/subjek yang mempunyai kualitas dan karakteristik tertentu yang ditetapkan oleh peneliti untuk dipelajari dan kemudian ditarik kesimpulannya menurut (Sugiyono, 2011). Jadi dapat disimpulkan bahwa populasi dari penelitian ini adalah seluruh peserta didik kelas IV di SD yang terdapat pada Gugus II Abiansemal yang terdiri dari 8 kelas dalam 8 sekolah dasar. Jumlah populasi dari penelitian ini 232 peserta didik. Selanjutnya adalah menentukan sampel.

Sampel adalah sejumlah kelompok kecil yang mewakili populasi untuk dijadikan sebagai objek penelitian. Untuk menentukan sampel, cara yang digunakan adalah dengan cara pengundian (random sampling). Cara undian dilakukan dengan menulis semua nama kelas IV di seluruh SD populasi pada masing-masing kertas yang jumlahnya 8 kelas, kemudian kertas digulung. Masukkan gulungan kertas ke dalam gelas dan dikocok. Ambil satu gulungan kertas yang dijatuhkan, lalu ambil gulungan kertas lain, tanpa memasukkan gulungan kertas pertama. Nama - nama SD pada kedua gulungan merupakan sampel penelitian. Setelah dilakukan pengudian diperoleh kelas yang menjadi sampel yaitu kelas IV SD No.1 Selat yang berjumlah 39 orang dan kelas IV SD No.2 Taman yang berjumlah 35 orang. Selanjutnya, dilakukan penyetaraan terhadap kedua sampel untuk memastikan tidak ada perbedaan rata-rata nilai kemampuan hasil belajar IPS peserta didik. Teknik yang digunakan dalam penyetaraan sampel adalah teknik matching. Cara penyetaraan dengan teknik maching dalam penelitian ini adalah dengan menjodohkan nilai pretest peserta didik dari kelompok kontrol dan kelompok eksperimen. Ini dilakukan dengan membuat peringkat nilai dari peserta didik yang tertinggi sampai yang terendah kemudian nilai yang sama menjadi satu 
pasangan. Jika terdapat nilai peserta didik yang tidak mendapatkan pasangan maka peserta didik tersebut tetap diikutkan dalam proses pemberian perlakuan saat penelitian, akan tetapi peserta didik tersebut tidak diikutkan sebagai sampel. Ini dilakukan agar tidak mengganggu psikologis peserta didik.

Metode pengumpulan data yang digunakan dalam penelitian ini adalah metode tes, dengan instrument berupa tes hasil belajar IPS adalah tes objektif dalam bentuk pilihan ganda biasa. Kemudian data dianalisis secara deskriptif, yaitu merupakan analisis yang dipakai untuk menganalisis data dengan mendeskripsikan atau menggambarkan data-data yang sudah dikumpul. Jika data yang diperoleh sudah memenuhi prasyarat uji normalitas dan homogenitas maka analisis yang digunakan adalah statistik parametrik. Analisis statistik yang digunakan untuk menguji hipotesis penelitian ini adalah uji beda mean (uji t). Uji Hipotesis menggunakan uji-t dengan rumus sparated varians.

\section{Hasil dan Pembahasan}

Deskripsi data dalam penelitian ini memaparkan rata-rata (mean), standar deviasi dan varians Hasil Belajar IPS pada kelompok eksperimen dan kelompok kontrol. Berdasarkan hasil perhitungan diperoleh nilai rata-rata hasil belajar IPS , pada kelompok eksperimen yang dibelajarkan dengan model Problem Based Learning berbasis portofolio adalah 78,57 dengan varians 96,25 dan standar deviasi 9,81. Berdasarkan hasil analisis statistik deskriptif hasil belajar IPS peserta didik kelompok eksperimen diperoleh nilai rata-rata, $\bar{X}=78,57$ dan rata-rata persentase hasil belajar IPS peseta didik kelompok eksperimen, $\mathrm{M} \%=78,57$. Rata-rata persentase hasil belajar IPS tersebut kemudian dikonsultasikan dengan tabel konversi PAP Skala Lima dan berada pada kategori cukup. Sedangkan pada kelompok kontrol yang dibelajarkan melalui pembelajaran konvensional adalah 72,17 dengan varians 53,59 dan standar deviasi 7,32. Berdasarkan hasil analisis statistik deskriptif hasil belajar IPS peserta didik kelompok kontrol diperoleh nilai rata-rata, $\bar{X}=72,17$ dan rata-rata persentase hasil belajar IPS peserta didik kelompok eksperimen, $\mathrm{M} \%=72,17$. Rata-rata persentase hasil belajar IPS tersebut kemudian dikonsultasikan dengan tabel konversi PAP Skala Lima dan berada pada kategori cukup.

Dari data tersebut diketahui bahwa nilai rata-rata yang diperoleh peserta didik kelompok eksperimen yang dibelajarakan melalui model Problem Based Learning (PBL) berbasis portofolio lebih tinggi dari nilai rata-rata yang diperolehpeserta didik kelompok kontrol yang dibelajarakan melalui pembelajaran konvensional. Uji prasyarat dilakukan terlebih dahulu sebelum uji hipotesis menggunakan uji-t. Uji prasyarat tersebut meliputi uji normalitas dan uji homogenitas varians.

Uji normalitas dilakukan untuk mengetahui sebaran frekuensi skor, untuk menguji hasil belajar IPS kelompok eksperimen dan kontrol. Uji normalitas data dilakukan pada kelompok eksperimen yang mengikuti pembelajaran menggunakan model Problem Based Learning berbasis portofolio dan kelompok kontrol yang mengikuti pembelajaran konvensional. Dalam uji normalitas digunakan analisis Chi-Kuadrat $\left(\chi^{2}\right)$ dengan taraf signifikan $5 \%$ dan derajat kebebasan $(\mathrm{dk})=\mathrm{k}-1$. Nilai $X_{\text {tabel }}^{2}$ pada taraf signifikansi 5\% $(\alpha=2,869)$ dan derajat kebebasan $(\mathrm{db})=5$ diperoleh $X_{\text {tabel }}^{2}=11,070$.

Berdasarkan hasil uji analisis kelompok eksperimen diperoleh $X_{\text {hitung }}^{2}=5,61$. Karena $X_{\text {hitung }}^{2}<X_{\text {tabel }}^{2}$ maka data berdistribusi normal. Ini berarti sebaran data kelompok eksperimen berdistribusi normal. Sedangkan hasil uji analisis kelompok kontrol diperoleh $X_{\text {hitung }}^{2}=3,00$ $X_{\text {hitung }}^{2}<X_{\text {tabel }}^{2}$ maka data berdistribusi normal. Ini berarti sebaran data kelompok kontrol berdistribusi normal. Selanjutnya dilakukan uji homogenitas varians kelompok eksperimen yang mengikuti Uji homogenitas varians data hasil belajar IPS kelompok eksperimen dan kelompok kontrol di peroleh $\mathrm{F}_{\text {hitung }}$ $=1,80$. Nilai tersebut kemudian dikonsultasikan dengan harga $F_{\text {tabel }}$ dengan taraf signifikansi $5 \%$ dengan derajat kebebasan (dk1) untuk pembilang n1-1 = 30-1 dan derajat kebebasan (dk2) untuk penyebut n2-1 $=30-1$. Jadi hasil analisis $F_{\text {tabel }}=1,84$ karena $F_{\text {hitung }} 1,80 \leq F_{\text {tabel }} 1,84$ maka dapat dikatakan data hasil belajar IPS kelompok eksperimen dan kelompok kontrol mempunyai varians yang homogen.

Berdasarkan hasil uji prasyarat yang terdiri dari uji normalitas dan uji homogenitas varians, disimpulkan bahwa data kedua kelompok sampel ialah berdistribusi normal dan memiliki varians yang homogen. Karena data yang diperoleh telah memenuhi prasyarat, uji hipotesis dilakukan dengan analisis uji-t. Adapun Kriteria pengujian yaitu $\mathrm{H}_{0}$ ditolak dan $\mathrm{H}_{\mathrm{a}}$ diterima jika harga $\mathrm{t}_{\text {hitung }}>\mathrm{t}_{\text {tabel }}$ sedangkan $\mathrm{H}_{0}$ diterima dan $\mathrm{H}_{\mathrm{a}}$ ditolak jika harga $\mathrm{t}_{\text {hitung }} \leq \mathrm{t}_{\text {tabel }}$. Harga $\mathrm{t}_{\text {tabel }}$ didapatkan dari tabel distribusi $t$ pada taraf signifikan $5 \%$ dengan derajat kebebasan $\mathrm{dk}=\mathrm{n}_{1}+\mathrm{n}_{2}-2$. Rekapitulasi hasil analisis uji-t kelompok sampel penelitian ini disajikan dalam tabel 1 berikut ini.

Table 1. Rekapitulasi Hasil Analisis Data Hasil Belajar IPS Menggunakan Uji-t 


\begin{tabular}{|c|c|c|c|c|c|c|c|c|}
\hline No & Sampel & $\mathrm{N}$ & Dk & $\bar{X}$ & $\mathrm{~S}^{2}$ & $t_{\text {hitung }}$ & $t_{\text {tabel }}$ & Status \\
\hline $\begin{array}{l}1 \\
2\end{array}$ & $\begin{array}{l}\text { Kelompok eksperimen } \\
\text { Kelompok kontrol }\end{array}$ & $\begin{array}{l}30 \\
30\end{array}$ & 58 & $\begin{array}{l}78,57 \\
72,17\end{array}$ & $\begin{array}{l}96,26 \\
53,59\end{array}$ & 2,869 & 2,000 & $\mathrm{H}_{0}$ ditolak \\
\hline
\end{tabular}

Dari hasil analisis diketahui bahwa sebaran data hasil belajar IPS peserta didik berdistribusi normal dan memiliki varians yang homogen. Dari hasil analisis diperoleh $t_{\text {hitung }}=2,869$ dan $t_{\text {tabel }}=2,000$ pada taraf signifikansi $5 \%$ dengan $\mathrm{dk}=\mathrm{n} 1+\mathrm{n} 2-2=(30+30-2)=58$. Oleh karena $\mathrm{t}_{\text {hitung }} 2,869>\mathrm{t}_{\text {tabel }} 2,000$ maka $\mathrm{H}_{0}$ ditolak. $\mathrm{H}_{\mathrm{a}}$ diterima yang menyatakan terdapat pengaruh yang signifikan hasil belajar ips antara kelompok peserta didik yang dibelajarkan dengan model Problem Based Learning (PBL) Berbasis Portofolio dan kelompok peserta didik yang dibelajarkan dengan pembelajaran konvensional pada kelas IV SD Gugus II Abiansemal Tahun Ajaran 2017/2018. Sehingga dapat dikatakan bahwa terdapat pengaruh yang signifikan hasil belajar ips antara kelompok peserta didik yang dibelajarkan dengan model Problem Based Learning (PBL) Berbasis Portofolio dan kelompok peserta didik yang dibelajarkan dengan pembelajaran konvensional pada kelas IV SD Gugus II Abiansemal Tahun Ajaran 2017/2018.

Berdasarkan hasil analisis data, diperoleh nilai rata - rata peserta didik kelompok eksperimen yang dibelajarkan menggunakan model Problem Based Learning Berbasis Penilaian Portofolio ( $\bar{X}=$ 78,57) dengan perolehan nilai terendah 59 dan nilai tertinggi 97. Sedangkan hasil rata-rata peserta didik yang dibelajarkan dengan pembelajaran konvensional ( $\bar{X}=72,17)$ dengan perolehan nilai terendah 56 dan nilai tertinggi 84. Berdasarkan kriteria Penilaian Acuan Patokan (PAP) skala 5 rerata kelompok eksperimen berada pada kriteria Cukup dan rerata pada kelompok kontrol berada pada kriteria Cukup.

Hasil perolehan rata-rata kelompok eksperimen dan kelompok kontrol memiliki perbedaan sebesar 6,4. Dari hasil analisis diketahui bahwa sebaran data hasil belajar IPS peserta didik berdistribusi normal dan memiliki varians yang homogen. Dari hasil analisis diperoleh $t_{\text {hitung }}=2,869$ dan $t_{\text {tabel }}=2,000$ pada taraf signifikansi $5 \%$ dengan $d k=n 1+n 2-2=(30+30-2)=58$. Oleh karena $t_{\text {hitung }} 2,869>t_{\text {tabel }} 2,000$ maka $\mathrm{H}_{0}$ ditolak yang menyatakan tidak terdapat pengaruh yang signifikan hasil belajar IPS antara kelompok peserta didik yang dibelajarkan dengan model Problem Based Learning berbasis penilaian portofolio dan kelompok peserta didik yang dibelajarkan dengan pembelajaran konvensional pada kelas IV SD Gugus II Abiansemal Tahun Ajaran 2017/2018 dan $\mathrm{H}_{\mathrm{a}}$ diterima yang menyatakan terdapat pengaruh yang signifikan hasil belajar IPS antara kelompok peserta didik yang dibelajarkan dengan model Problem Based Learning berbasis penilaian Portofolio dan kelompok peserta didik yang dibelajarkan dengan pembelajaran konvensional pada kelas IV SD Gugus II Abiansemal Tahun Ajaran 2017/2018. Sehingga dapat dikatakan bahwa terdapat pengaruh yang signifikan hasil belajar IPS antara kelompok peserta didik yang dibelajarkan dengan model Problem Based Learning Berbasis Penilaian Portofolio dan kelompok peserta didik yang dibelajarkan dengan pembelajaran konvensional pada kelas IV SD Gugus II Abiansemal Tahun Ajaran 2017/2018.

\section{Simpulan dan Saran}

Berdasarkan hasil analisis data hasil belajar IPS pada kelompok eksperimen terdapat 30 peserta didik dengan nilai tertinggi yang diperoleh 97 dan nilai terendah adalah 59. Dari sebaran data tersebut diperoleh data rata-rata (mean) adalah 78,57 yang berdasarkan PAP skala 5 termasuk kriteria cukup dan hasil analisis data hasil belajar IPS pada kelompok kontrol terdapat 30 peserta didik dengan nilai tertinggi yang diperoleh 84 dan nilai terendah adalah 56. Dari sebaran data tersebut diperoleh data rata-rata (mean) adalah 72,17 yang berdasarkan PAP skala 5 termasuk kriteria cukup.

Dari hasil analisis diketahui bahwa sebaran data hasil belajar IPS peserta didik berdistribusi normal dan memiliki varians yang homogen. Dari hasil analisis diperoleh $t_{\text {hitung }}=2,869$ dan $t_{\text {tabel }}=2,000$ pada taraf signifikansi $5 \%$ dengan $\mathrm{dk}=58$. Oleh karena $\mathrm{t}_{\text {hitung }} 2,869>\mathrm{t}_{\text {tabel }} 2,000000$ maka $\mathrm{H}_{0}$ di tolak yang menyatakan bahwa tidak terdapat terdapat pengaruh yang signifikan hasil belajar IPS kelompok peserta didik yang dibelajarkan melalui model Problem Based Learning (PBL) berbasis Portofolio dengan kelompok peserta didik yang dibelajarkan dengan pembelajaran konvensional pada kelas IV SD Gugus II Abiansemal tahun ajaran 2017/2018 dan $\mathrm{H}_{\mathrm{a}}$ diterima yang menyatakan bahwa terdapat pengaruh yang signifikan hasil belajar IPS kelompok peserta didik yang dibelajarkan melalui model Problem Based Learning (PBL) berbasis Portofolio dengan kelompok peserta didik yang dibelajarkan dengan pembelajaran konvensional pada kelas IV SD Gugus II Abiansemal tahun ajaran 2017/2018.

Dilihat dari rata-rata kelompok peserta didik yang dibelajarkan melalui model Problem Based Learning (PBL) berbasis Portofolio $\bar{X}=78,57>\bar{X}=72,17$ kelompok peserta didik yang dibelajarkan dengan pembelajaran konvensional. Jadi dapat disimpulkan bahwa model Problem Based Learning (PBL) berbasis Portofolio berpengaruh terhadap hasil belajar IPS Siswa Kelas IV SD Gugus II Abiansemal tahun 
ajaran 2017/2018. Adapun saran yang dapat disampaikan setelah dilaksanakan dan diperoleh hasil dari penelitian ini yaitu sebagai berikut. Kepada Guru, berdasarkan simpulan penelitian yang diperoleh, disarankan kepada guru agar lebih kreatif untuk memberikan fasilitas berupa sumber belajar dan kesempatan yang lebih besar bagi pesrta didik pada pembelajaran yang menggunakan model Problem Based Learning (PBL) berbasis Portofolio dan dapat dijadikan alternatif dalam proses pembelajaran untuk membantu peserta didik meningkatkan hasil belajar IPS dengan maksimal. Kepada Kepala Sekolah, berdasarkan simpulan penelitian, disarankan kepada kepala sekolah agar dapat menggunakan hasil penelitian ini sebagai alternatif dalam mengelola pembelajaran agar sesuai dengan karakteristik pembelajaran IPS, sehingga mampu meningkatkan hasil belajar peserta didik tentang IPS. Kepada Peneliti Lain, berdasarkan simpulan penelitian, diharapkan kepada peneliti lain agar hasil penelitian ini digunakan sebagai suatu acuan bagi peneliti lain untuk mengembangkan kemampuan diri dalam mempersiapkan model dan metode pembelajaran sehingga mampu memberikan pengaruh yang positif di bidang pndidikan dan tentunya dapat mengoptimalkan hasil belajar peserta didik.

\section{Daftar Rujukan}

Agung, A.A.G. 2014. Buku Ajar Metodelogi Penelitian Pendidikan. Yogyakarta: Aditya Media Publishing.

Agung, A.A.G. 2016. Statistika Dasar untuk Pendidikan. Yogyakarta: Deepublish.

Amir, Taufiq. 2009. Inovasi Pendidikan Melalui Problem Based Learning. Jakarta: Prenadamedia Group.

Arikunto, Suharsimi. 2015. Dasar-dasar Evaluasi Pendidikan. Jakata: Bumi Aksara.

Ariswati, Ni Putu Eva Adelina. 2017. Pengaruh Model Problem Based Learning Berbantuan Media Question Card Terhadap hasil belajar IPS Siswa Kelas V SD di Gugus III Kecamatan Melaya KaBupaten Jembrana Tahun Pelajaran 2016/2017. Singaraja: Universitas Pendidikan Ganesha: Vol 6no: 1.

Dantes, N. 2012.Metode Penelitian. Yogyakarta: Andi Yogyakarta.

Dewi, Ayu Risa Fratika. 2017. Pengaruh Model Problem Based Learning Berbantuan Media AudioVisual Terhadap Hasil Belajar IPS Siswa Kelas IV SD Gugus VII Kuta Selatan Tahun Pelajaran 2016/2017. Denpasar: Universitas Pendidikan Ganesha: Vol 5 no: 2.

Dwiyanto, Firman dan Miftahus Suhur. 2016. STRATEGI PEMBELAJARAN BERBASIS MASALAH. www.nulisbuku.com.

Gunawan, Rudy. 2016. Pendidikan IPS. Bandung: Alfabeta.

Muslich, Masnur. 2007. KTSP Dasar Pemahaman dan Pengembangan. Jakarta: PT Bumi Aksara.

Nurkholis. 2013. Pendidikan Dalam Upaya Memajukan Teknologi . Jurnal Kependidikan, Vol. 1 No. 1 Nopember 2013

Putra, I Gede Hery Suyasa. 2017. Pengaruh Model Picture And Picture Dengan Penilaian Portofolio Terhadap Hasil Belajar IPA Siswa Kelas IV SD di Gugus I Sriwijaya Kecamatan Pakutatan Tahun Pelajaran 2016/2017. Singaraja. Universitas Pendidikan Ganesha: Vol 6 no:1.

Rasana, I Dewa Putu Raka. 2009. Model-model Pembelajaran. Sinagaraja: Universitas Pendidikan Ganesha.

Ratnawulan, Elis. 2015. Evaluasi Pembelajaran. Bandung: CV Pustaka Setia.

Rusman. 2016. Model-Model Pembelajarn Mengembangkan Profesionalisme Guru. Jakarta: PT Rajagrafindo Persada.

Sani, Ridwan Abdullah. 2015. Pembelajaran Saintifik Untuk Implementasi Kurikulum 2013. Jakarta: Bumi Aksara.

Sanjaya, Wina. 2009. Kurikulum dan Pembelajaran. Jakarta: Kencana Prenada Media Group. 
Setyosari, H. Punaji. 2015. Metode Penelitian Pendidikan dan Pengembangan. Jakarta: Kencana.

Shoimin, Aris. 2014. 68 Model Pembelajaran Inovatif dalam Kurikulum 2013. Yogyakarta: Ar-Ruzz Media.

Sugiyono. 2011. Metode Penelitian Kuantitatif, Kualitatif, dan R\&D. Bandung: Alfabeta.

Sugiyono,2012.Metode Penelitian Pendidikan. Bandung: Alfabeta, cv.

Sumantri, Mohamad Syarif. 2015. Strategi Pembelajaran. Jakarta: PT. Rajagrafindo Persada.

Surapranata, Sumarn. 2007.Penilaian Portofolio Implementasi Kurikulum 2004. Bandung: PT Remaja Rosdakarya.

Susanto, Ahmad. 2013. Teori Belajar \& Pembelajaran di Sekolah Dasar. Jakarata: Prenamedia Group.

Undang - Undang Republik Indonesia no.20 Tahun 2003 tentang Sisitem PendidikanNasional. 2016.Jakarta:http://kelembagaan.restekdikti.go.id/wpcontent/uploads/2016/08/UU no 20 th 20 03.pdf

Yus, Anita. 2006. Penilaian Portofolio Untuk Sekolah Dasar. Departemen Pendi dikan Nasional. 